\title{
Evaluation of Genetic Diversity of Seedling Raised Pecan Nut (Carya illinoensis K.) for Tree Growth Habit
}

\author{
Kiran Thakur*, Girish Sharma, Paramjeet Sajwan, Deepika and Heerendra Prasad
}

Dept. of Fruit Science, College of Horticulture, DrYS Parmar University of Horticulture and Forestry, Nauni, Solan, HP (173 230), India

\section{Corresponding Author}

Kiran Thakur

e-mail: thakur.kanu@ymail.com

\author{
Article History \\ Article ID: IJEP0283 \\ Received in $12^{\text {th }}$ February, 2019 \\ Received in revised form $20^{\text {th }}$ February, 2019 \\ Accepted in final form 23 $3^{\text {rd }}$ February, 2019
}

\begin{abstract}
The present investigation entitled evaluation of diversity for tree growing habit in seedling raised pecan nut [Carya illinoensis (Wang) $\mathrm{K}$. Koch] was carried out to document the available genetic variability in pecan nut germplasm and to select elite pecan nut genotypes possessing superior attributes and quality traits. During the study, data was recorded on seventy pecan nut trees growing in experimental field orchard of Department of Fruit science YSPUHF, Nauni, Solan (HP). Remarkable variability was observed in seedling pecan nut trees for tree growth characters viz., tree growth habit, density of branching and shoot colour of one year old shoot. In this study 12 (17.14\%) seedlings had upright growth habit, 33 (47.14\%) were semi-upright and 25 (35.72\%) were of spreading growth habit. 5 (7.14\%) seedling trees possessed sparsely dense branching, 32 (45.72\%) exhibited medium and 33 (47.14\%) had highly dense branching. Twenty six (37.14\%) seedling trees possessed greenish brown colour of one year old shoot, $38(54.29 \%)$ had medium brown and 6 (8.57\%) had reddish brown colour of one year old shoot.
\end{abstract}

Keywords: Branching density, Carya illinoensis, diversity, evaluation, pecan nut

\section{Introduction}

The pecan nut [Carya illinoensis (Wang) K. Koch] is one of the better known hickories. It is also famous as 'queen of nuts' and belongs to the family Juglandaceae. Pecan is native to North America and also exists in Texas and North of Mexico (Andersen and Crocker, 2012). Pecan nut thrives best in the areas which are considered somewhat lower in altitude and hotter for walnut cultivation (Sparks, 2000). In India pecan is very important temperate nut crop (next to walnut and almond) of colder areas covering an area of 1.14 thousand hectares with an annual production of approximate 0.19 thousand metric tonnes and is widely grown in Himachal Pradesh and Jammu and Kashmir (NHB, 2015). Pecans were introduced from USA (eight cultivars) by Punjab government in 1937 in India and were planted at Govt. Fruit Farm, Palampur, Himachal Pradesh, which became major source of planting material in Himalayan region.. Pecan nut has the recognition of being called "queen of nuts" because of its excellent kernel characteristics. Pecan having (flavor, $65-70 \%$ fats, $8-10 \%$ proteins, high in phosphorous, potassium and vitamins $A, C$, $E$ and $B$ complex) is superior to walnut in quality and thrives best in areas which are considered lower and hotter for walnut cultivation (Singh et al., 2011). Though introduced in Palmpur,
Himachal Pradesh, way back in this nut crop could not assume commercial status for the want of suitable cultivars among orchardists, also this nut crop has huge potential for commercialisation being hardy to climatic vagaries and having export value. The motivation behind this study is to examine the degree of diversity in seedling pecan nut trees which has been planted in Nauni region of Solan district in Himachal Pradesh. These results will provide guidance about effective management, conservation, and improvement of pecan nut resources. In addition, the recent trends of expanding agriculture, increased urbanization and gigantic population growth are adding continuously to the extinction and genetic erosion of valuable pecan nut germplasm. Thus, there is a crucial need for exploration and conservation of the existing high quality pecan nut germplasm growing in this region.

The present study was conducted on pecan nut seedling selections planted in Experimental Farm of Department of Fruit science, YSPUHF, Nauni, Solan to estimate the extent of genetic variability and relationship by studying tree morphological character.

\section{Materials and Methods}

The present investigation was carried out during the years 
2015-2017 in Experimental Farm of Department of Fruit science, YSPUHF, Nauni, Solan. The study area is situated at $30.85^{\circ}$ north latitude and $77.17^{\circ}$ east longitude at an altitude of about 1300 meters above sea level.

Seventy plants of seedling origin genotypes with divergent tree characters were selected. Codes were allotted to each genotype (as STN stands for seedling tree number). Regular visits were made and observation on different tree characters i.e., tree growth habit, density of canopy and one year old shoot colour were made at different stages of plant growth using different pecan nut descriptors given by UPOV (The International union for the protection of new varieties of plants) guidelines (UPOV, 2014).

The growth habit of all the pecan selections and cultivars was studied in the month of January during dormancy. Based on visual observations on spread of side branches and their competition with the central leader, each individual tree was grouped in one of the following categories:

\begin{tabular}{ll}
\hline 1. Upright & $\begin{array}{l}\text { Branches grow conspicuously upward } \\
\text { and tend to compete with central leader }\end{array}$ \\
2. Semi-upright & $\begin{array}{l}\text { Branches grow upward and do not tend } \\
\text { to compete with central leader. }\end{array}$ \\
3. Spreading & $\begin{array}{l}\text { Side branches were spreading upward } \\
\text { and do not compete with central leader. }\end{array}$ \\
\hline
\end{tabular}

On the basis of visual observations, colour of one year old shoots in each case was recorded in January. The categories made were greenish brown, medium brown and reddish brown. Number of secondary branches per metre shoot length of primary scaffold branches was counted in all the four directions of the tree to work out the average density of branching, and accordingly various selections/cultivars under study were categorized as sparse, medium, dense.

\section{Results and Discussion}

Tree characteristics are very important as far as diversity is concerned. In this study seedling pecan nut trees surveyed from different locations showed variability in tree characters.

The tree growth habit varied and was observed as upright, semi-upright and spreading. Out of 70 pecan nut genotypes $12(17.14 \%)$ seedling origin pecan nuts had upright type of tree habit, 33 (47.14\%) had semi-upright type of tree growth habit while remaining $25(35.72 \%)$ had spreading tree growth habit. Maximum (47.14\%) were semi-upright in growth habit. Findings for tree growth habit are in agreement with the research observations by Grauke and Thomson (1996), Sharma (1977), Kaushal and Sharma (2005), Hensz et al. (1983), Sparks (1995) who also observed similar type of growth habit in seedling population as well as in the pecan cultivars. Recently, Rani et al. (2018) studied diversity in the tree growth habit in Jammu Province and the present data is very similar to their work. In walnut Akhiani et al. (2017) also recorded similar variation in growth habit, whereas semi spreading nature was more prevalent than other growth types (Table 1).

Table 1: Variation in growth habit, shoot colour, density of branching, regularity in bearing in seedling population of pecan

\begin{tabular}{|c|c|c|c|}
\hline $\begin{array}{l}\text { Tree } \\
\text { no. }\end{array}$ & Growth habit & Shoot colour & $\begin{array}{l}\text { Density of } \\
\text { branching }\end{array}$ \\
\hline STN1 & Spreading & Medium brown & Medium \\
\hline STN2 & Spreading & Greenish brown & Dense \\
\hline STN3 & Semi-upright & Medium brown & Sparse \\
\hline STN4 & Spreading & Greenish brown & Dense \\
\hline STN5 & Semi-upright & Medium brown & Dense \\
\hline STN6 & Spreading & Medium brown & Dense \\
\hline STN7 & Spreading & Greenish brown & Sparse \\
\hline STN8 & Semi-upright & Greenish brown & Dense \\
\hline STN9 & Spreading & Greenish brown & Dense \\
\hline STN10 & Upright & Medium brown & Medium \\
\hline STN11 & Semi-upright & Greenish brown & Medium \\
\hline STN12 & Semi-upright & Medium brown & Medium \\
\hline STN13 & Spreading & Medium brown & Sparse \\
\hline STN14 & Semi-upright & Greenish brown & Dense \\
\hline STN15 & Semi-upright & Medium brown & Sparse \\
\hline STN16 & Upright & Greenish brown & Dense \\
\hline STN17 & Semi-upright & Medium brown & Medium \\
\hline STN18 & Upright & Medium brown & Medium \\
\hline STN19 & Semi-upright & Greenish brown & Dense \\
\hline STN20 & Spreading & Medium brown & Dense \\
\hline STN21 & Semi-upright & Greenish brown & Medium \\
\hline STN22 & Spreading & Reddish brown & Dense \\
\hline STN23 & Semi-upright & Reddish brown & Medium \\
\hline STN24 & Spreading & Medium brown & Dense \\
\hline STN25 & Spreading & Medium brown & Medium \\
\hline STN26 & Upright & Greenish brown & Medium \\
\hline STN27 & Semi-upright & Medium brown & Medium \\
\hline STN28 & Upright & Medium brown & Medium \\
\hline STN29 & Spreading & Medium brown & Dense \\
\hline STN30 & Semi-upright & Reddish brown & Medium \\
\hline STN31 & Semi-upright & Greenish brown & Medium \\
\hline STN32 & Semi-upright & Greenish brown & Dense \\
\hline STN33 & Spreading & Medium brown & Dense \\
\hline STN34 & Semi-upright & Medium brown & Medium \\
\hline STN35 & Spreading & Reddish brown & Medium \\
\hline STN36 & Spreading & Medium brown & Dense \\
\hline
\end{tabular}




\begin{tabular}{|c|c|c|c|}
\hline $\begin{array}{l}\text { Tree } \\
\text { no. }\end{array}$ & $\begin{array}{c}\text { Growth } \\
\text { habit }\end{array}$ & Shoot colour & $\begin{array}{l}\text { Density of } \\
\text { branching }\end{array}$ \\
\hline STN37 & Semi-upright & Greenish brown & Dense \\
\hline STN38 & Spreading & Medium brown & Dense \\
\hline STN39 & Semi-upright & Medium brown & Dense \\
\hline STN40 & Spreading & Greenish brown & Medium \\
\hline STN41 & Upright & Greenish brown & Dense \\
\hline STN42 & Semi-upright & Greenish brown & Dense \\
\hline STN43 & Spreading & Medium brown & Dense \\
\hline STN44 & Upright & Medium brown & Medium \\
\hline STN45 & Semi-upright & Medium brown & Medium \\
\hline STN46 & Semi-upright & Greenish brown & Medium \\
\hline STN47 & Spreading & Greenish brown & Dense \\
\hline STN48 & Semi-upright & Medium brown & Dense \\
\hline STN49 & Semi-upright & Medium brown & Dense \\
\hline STN50 & Upright & Medium brown & Dense \\
\hline STN51 & Semi-upright & Medium brown & Medium \\
\hline STN52 & Upright & Greenish brown & Medium \\
\hline STN53 & Semi-upright & Medium brown & Dense \\
\hline STN54 & Spreading & Medium brown & Dense \\
\hline STN55 & Semi-upright & Greenish brown & Medium \\
\hline STN56 & Spreading & Greenish brown & Dense \\
\hline STN57 & Semi-upright & Greenish brown & Medium \\
\hline STN58 & Spreading & Medium brown & Dense \\
\hline STN59 & Spreading & Medium brown & Medium \\
\hline STN60 & Upright & Medium brown & Medium \\
\hline STN61 & Semi-upright & Reddish brown & Medium \\
\hline STN62 & Upright & Greenish brown & Medium \\
\hline STN63 & Upright & Medium brown & Dense \\
\hline STN64 & Semi-upright & Greenish brown & Medium \\
\hline STN65 & Semi-upright & Medium brown & Medium \\
\hline STN66 & Semi-upright & Greenish brown & Sparse \\
\hline STN67 & Spreading & Medium brown & Dense \\
\hline STN68 & Semi-upright & Medium brown & Medium \\
\hline STN69 & Spreading & Medium brown & Dense \\
\hline STN70 & Semi-upright & Reddish brown & Medium \\
\hline
\end{tabular}

The accessions showed variation in density of branching i.e., sparse, medium and dense. Out of seventy seedling origin pecan nut genotypes $6(8.57 \%)$ were having sparse, 32 (45.72\%) were having medium dense and 33 (47.14\%) were having dense branching. These results are similar to the results of Lone (2017), who observed that out of 150 seedling genotypes of walnut maximum (65) were having dense canopy (Table 2).
Table 2: Effect of cutting length on the growth parameters of Populus deltoids under nursery conditions

\begin{tabular}{llcc}
\hline Characteristics & \multicolumn{1}{c}{$\begin{array}{c}\text { Extent of } \\
\text { variation }\end{array}$} & $\begin{array}{c}\text { Frequency } \\
\text { (No. of gen- } \\
\text { otypes) }\end{array}$ & $\begin{array}{c}\text { Percent- } \\
\text { age }\end{array}$ \\
\hline Growth habit & Upright & 12 & 17.14 \\
& Semi-upright & 33 & 47.14 \\
& Spreading & 25 & 35.72 \\
Shoot colour & Greenish & 26 & 37.14 \\
& brown & & \\
& Medium & 38 & 54.29 \\
& brown & & \\
& Reddish brown & 6 & 8.57 \\
Density of & Dense & 33 & 47.14 \\
branching & Medium & 32 & 45.72 \\
& Sparse & 5 & 7.14 \\
\hline
\end{tabular}

One year old shoot colour was categorised as greenish brown, medium brown and brown with greenish brown observed in $26(37.14 \%)$ seedling origin pecan nut, medium brown in 38 (54.29\%) genotypes and brown in $6(8.57 \%)$ genotypes. Out of 70 seedling pecan nut trees maximum were having medium brown. In a similar study Sharma (1977) observed that colour of one year old shoot varied from medium brown, greenish brown to brown in walnut seedling trees growing in Himachal Pradesh.

\section{Conclusion}

To assess the relative magnitude of the existing genetic diversity is necessary to build a data base by putting all the information together with other selection parameters for the improvement of nut yield. The extent of genetic variability indicates the potential of exercising selection of a particular genotype. Accessing variability/diversity for tree growth traits in pecan nut populations (seedling origin) and subsequent identification of evaluated superior genotype is a must for further breeding programme in pecan nut.

\section{References}

Akhiani, S., Afshari, H., Parvaneh, T., 2017. Evaluation of some phenological and pomological characteristics of selected Walnut genotypes from Shahroud-Iran. Journals of Nuts 8, 21-30.

Andersen, P.C., Crocker, T.E., 2012. The pecan tree. EDIS Publication HS982, 17. Department of Horticultural Sciences, Institute of Food and Agricultural Sciences, University of Florida, Gainesville, FL.

Grauke, L.J., Thompson, T.E., 1996. In Fruit Breeding vol. III: Nuts, Janick, J., Moore, J.N., (Ed.), Purdue Univ. Press, USA, 185-239.

Lone, I.A., 2017. Estimation of variability and genetic 
parameters for kernel quality traits (protein and oil content) in the seedling raised natural walnut (Juglans regia $\mathrm{L}$.) population in the Kashmir valley. International Journal of plant sciences 12, 258-261.

NHB, 2015. NHB database. http//www.nhb.gov.in

Rani, S., Sharma, A., Wali V.K., Kour, K., Sharma, M., Gupta, R., 2018. Diversity for tree growing habit in the natural population of pecan nut (Carya illinoensis K.) in Jammu Province, India. International Journal of Current Microbiology and Current Sciences 7, 2761-2767.

Sharma, R. K., 1977. Studies on genetic variability in respect to tree and fruit characters in seedling pecan. M.Sc Thesis, Himachal Pradesh Agriculture University, Solan.
Singh, D., Kumar, K., Sharma, S.D., Sharma, V.K., 2011. Selection of indigenous pecan [Carya illinoensis (Wang.) K. Koch.] Trees for better nut and kernel quality characters. Journal of Hill Agriculture 2, 85-89.

Sparks, D., 2000. Fruit set in pecan Carya illinoensis. Acta Horticulturae 527, 35-48.

UPOV., 2012. Guidelines for the conduct of tests for distinctness, uniformity and stability, pecan nut (Carya Illinoensis K.) UPOV-TG/Pecan (Proj.10). International union for the protection of new varieties of plants (UPOV), Geneva, 26. 